\title{
Introduction to "Soviet and Post-Soviet Sexualities”
}

\author{
Richard C. M. Mole
}

In June 2013 the issue of sexuality in Russia came under the global media spotlight, when Vladimir Putin signed into law a bill banning the spread of "propaganda of non-traditional sexual relations." While the law was justified by Putin as a means to boost Russia's falling birth rate and to uphold traditional Russian values, it was understood by critics as an attempt to shore up support among nationalist and conservative voters and discredit his political opponents. While the "gay propaganda law" triggered an immediate international outcry, for LGBT Russians the politicization of homosexuality was nothing new. Throughout the history of Soviet and post-Soviet Russia, the legal status of and attitudes towards homosexuals have always been strongly influenced by political discourse. While sexual desire can be understood as being biologically driven, sexual categories and the meanings assigned to them are constructed by institutions that "produce and/or reproduce ideologies and norms, which define social expectations" with regard to acceptable sexual mores and behaviors. ${ }^{1}$ The introduction to this cluster thus aims to show how homosexuality has been constructed and reconstructed in the USSR and post-Soviet Russia in a bid to provide the social and political context for the four articles that follow.

While Lenin considered "transgressive sexual behavior" to be bourgeois and insisted that there was no place for it "in the class-conscious, fighting proletariat," the Soviet regime nevertheless repealed the tsarist laws of 1832 banning male homosexuality following the October Revolution and, more significantly, refrained from introducing equivalent articles in the first Soviet Russian Criminal Code of $1922 .^{2}$ Sodomy was, however, criminalized in Azerbaijan, Uzbekistan, and Turkmenistan in the 1920s. ${ }^{3}$ Although consensual sexual relations between men were not illegal in Soviet Russia, Bolshevik intellectuals nevertheless prioritized ideology over sexuality, insisting on the "wholesale subordination of sexuality to the proletariat's class interests ...

1. Aleksandar Štulhofer and Theo Sandfort, eds., Sexuality and Gender in Postcommunist Eastern Europe and Russia (New York, 2005), 5.

2. Dan Healey, Homosexual Desire in Revolutionary Russia: The Regulation of Sexual and Gender Dissent (Chicago, 2001), 113; John N. Hazard, "Unity and Diversity in Socialist Law," Law and Contemporary Problems 30, no.2 (Spring 1965), 270-90.

3. Dan Healey, "Masculine Purity and "Gentlemen's Mischief”: Sexual Exchange and Prostitution between Russian Men, 1861-1941,” Slavic Review 60, no. 2 (Summer 2001), 258. 
for the sake of the Soviet state and Communist Party." ${ }^{4}$ Accordingly, in a society in which all citizens were expected to put the collective interest above individual desire, homosexuality was soon reconceived as abnormal, deviant, decadent and-in that it could not produce children-contrary to the public good. ${ }^{5}$ Intolerance towards homosexuality intensified under Stalin in part due to the changing nature of Party elites, whereby intellectuals and urban Marxists were replaced by peasants, resulting in increased anti-intellectualism. As homosexuality was constructed in ideological terms as a form of "decadent bourgeois morality," which would disappear with the establishment of communism, the oppression of gay men had "as much to do with their class backgrounds (as perceived by the regime) as with their homosexuality." 6 The decriminalization of homosexuality in 1934 was therefore hailed as a "triumph of proletarian humanitarianism," with Nikolai Krylenko, Soviet Commissar for Justice, proclaiming that after fifteen years of socialism "there was no reason for anyone to be homosexual" and anyone continuing to do so must be "remnants of the exploiting classes." Sexual relations between women, meanwhile, had never been criminalized and were not criminalized in 1934. Lesbians and bisexual women were treated not as criminals but rather as mentally ill and often subjected to medical and psychiatric interventions. ${ }^{8}$

Given its construction in ideological terms, the continued existence of homosexuality in the Soviet Union would have been taken as a sign of the failure of socialism to eradicate the lingering influence of the bourgeoisie, and it was thus imperative not just for homosexual sex to be illegal but also for homosexuals to be rendered invisible. References to same-sex desire were all but absent in the Soviet press and removed from all translations of foreign literature, while gatherings of gays and lesbians in the public sphere were forbidden. ${ }^{9}$ While Brian Baer suggests that, as a result, "Soviet culture offered little ontological basis for the representation of homosexuality as an identity, as a stable subject position through which one might assume a voice in the Russian public sphere," this view is not shared by the author of the first article in the cluster. ${ }^{10}$ While taking into account the effects produced by ideology

4. Igor S. Kon, "Sexuality and Politics in Russia, 1700-2000," in Franz X. Eder, Lesley A. Hall, and Gert Hekma, eds., Sexual Cultures in Europe. National Histories (Manchester, 1999), 208.

5. Lynne Attwood, "Young People, Sex and Sexual Identity,” in Hilary Pilkington, ed., Gender, Generation and Identity in Contemporary Russia (London, 1996), 102.

6. Patrick Pollard, "Gide in the USSR: Some Observations on Comradeship," Journal of Homosexuality 29, no. 2-3 (1995), 186; Simon Karlinsky, "Russia's Gay Literature and Culture: The Impact of the October Revolution," in Martin Duberman, Martha Vicinus, and George Chauncey, Jr., eds., Hidden from History: Reclaiming the Gay and Lesbian Past (New York, 1989), 360.

7. Around 1,000 gay men a year were imprisoned in the 1960s, 1970s, and 1980s; Daniel D. Healey, "Russia," glbtq: An Encyclopedia of Gay, Lesbian, Bisexual, Transgender, and Queer Culture, at http://www.glbtqarchive.com/ssh/russia_S.pdf (accessed September 3, 2015), 9.; Vanessa Baird, The No-Nonsense Guide to Sexual Diversity (Oxford 2007), 71.

8. See Laurie Essig, Queer in Russia: A Story of Sex, Self and the Other (Durham, 1999).

9. Brian J. Baer, "Now You See It: Gay (In)Visibility and the Performance of Post-Soviet Identity," in Nárcisz Fejes and Andrea P. Balogh, eds., Queer Visibility in Post-Socialist Cultures (Bristol, 2013$), 37$.

10. Ibid., 38. 
and medical and penal discourse, Arthur Clech argues that Russian men and women in the USSR were nevertheless able to construct homosexual subjectivities that were not reduced to either sickness or criminality but were rather created through language, irony, and solidarity.

While the 1960s and 1970s saw homosexuality decriminalized elsewhere in the communist bloc (in Czechoslovakia and Hungary in 1962, in the GDR and Bulgaria in 1968 and in Yugoslavia in 1977), calls for the decriminalization of consensual sex between men in the USSR were rejected. The second article in the cluster analyzes the debate between academics and Soviet criminologists between 1960 and 1975, showing how the case for decriminalization made by scholars on the basis of sexuality research was rejected for reasons of communist morality by criminologists affiliated with the Interior Ministry. Homosexual acts between men thus remained a crime until the end of the USSR. While some gays, lesbians, and bisexuals did succeed in living their lives on their own terms in the private sphere, there were few, if any, positive representations of homosexuality in the public sphere to counter the statesanctioned homophobia that shaped the opinions of generations of citizens throughout the Soviet era and beyond.

In 1993, just two years after the collapse of the USSR, consenting sexual acts between adult men were decriminalized in a bid to facilitate Russia's membership of the Council or Europe-but it was on the understanding that gays and lesbians would remain out of sight. ${ }^{11}$ In all societies, even socially liberal ones, "most people feel that sexuality belongs to the private space of the home" and as a result "most public spaces are coded to be heterosexual."12 While heterosexuals are able to express their sexuality publicly and so "transcend the so-called public-private dichotomy," gays and lesbians have historically been expected to remain invisible by performing traditional masculine and feminine behavior and/or keeping to their own spaces, such as gay and lesbian bars and clubs. ${ }^{13}$ In the immediate post-Soviet years LGBT Russians appear to have adhered to this "sexual contract," although more radical groups used the new post-decriminalization environment to engage in queer activism aimed at shocking Russian society. ${ }^{14}$ In the mid-nineties, LGBT community organizations and publications mushroomed across Russia, but their numbers dwindled to almost nothing by the early years of the new millennium in the face of official harassment and cuts in overseas funding. Nevertheless, gays and lesbians in Russia were now more visible than ever before.

The fact that the apparently sudden appearance of homosexuality in the public sphere coincided with the political and economic turmoil and the rapid demographic decline in Russia in the post-Soviet transition gave the impression that homosexuality was a "symptom of post-Soviet Russia's decline and ...

11. Homosexual acts were decriminalized in all former Soviet republics, with the exception of Uzbekistan and Turkmenistan.

12. G. Valentine, "(Hetero)Sexing Space: Lesbian Perceptions and Experiences of Everyday Spaces,” Environment and Planning D: Society and Space 11, no. 4 (1993), 396.

13. Ibid.

14. Essig, Queer in Russia, 62. 
a threat to Russia's already embattled social order."15 In contexts of massive and disorientating political, economic, and social change, any form of "cultural diversity seems threatening" and there is therefore often a tendency to "cling to traditional gender roles and sexual norms ... in an attempt to maximize predictability in an uncertain world." 16 In Russia this process was considered all the more important in view of the perceived distortion of "traditional" gender roles by the Soviet state. ${ }^{17}$ As "the main criterion of masculinity" in the years of the El'tsin presidency was associated with the ability to be the main breadwinner, the demasculinization of Russian men was exacerbated by the harsh economic realities of post-communism. ${ }^{18}$ Interestingly, in the 1990s, Russia itself was also thought to have been demasculinized by the loss of the Cold War, the dissolution of the USSR, the loss of the Soviet empire, the loss of superpower status, the economic collapse, the need to depend on foreign loans, and the failure to control the secessionist movement in Chechnya. The path to the restoration of Russian national pride, which according to Eliot Borenstein was interpreted as being inseparable from male dignity and sexuality, was thus via the retraditionalization of "national" gender roles and the remasculinization of Russia. ${ }^{19}$

In this context, men are traditionally the defenders of and decisionmakers on behalf of women, embodying the virtues of "willpower, honour, courage" needed to inspire action in the name of the nation. ${ }^{20}$ However, as Georg Mosse argues, the "ideal of masculinity ... as a symbol of personal and national regeneration" requires a countertype, against which the normative masculine ideal is strengthened and legitimized. ${ }^{21}$ These countertypes, of which homosexuals are a key group, do not just represent different types of masculinity but are constructed as "enemies," whereby the "line between modern masculinity and its enemies had to be sharply drawn in order that manliness as the symbol of a healthy society might gain strength from this contrast." 22 The same argument can, of course, be made for lesbians in relation to heterosexual women. In this context, as I argue elsewhere, homosexual men and women "are thought to threaten this national narrative by undermining the patriarchal family, failing to adhere to national stereotypes of masculinity and femininity, confusing the public/private roles of men

15. Baer, "Now you see it: gay (in)visibility and the performance of post-Soviet identity," 40.

16. Ronald Inglehart and Wayne E. Baker, "Modernization, Cultural Change, and the Persistence of Traditional Values," American Sociological Review 65, no. 1 (February 2000), 28.

17. See Sarah Ashwin, "Introduction: Gender, State and Society in Soviet and postSoviet Russia," in Sarah Ashwin, ed. Gender, State and Society in Soviet and post-Soviet Russia (London, 2000), 1-29.

18. Oleg Riabov and Tatiana Riabova, "The Remasculinization of Russia? Gender, Nationalism, and the Legitimation of Power under Vladimir Putin," Problems of PostCommunism 61, no. 2 (2014), 25.

19. Cited in Oleg Riabov and Tatiana Riabova, “The Remasculinization of Russia?,” 25.

20. Joane Nagel, "Masculinity and Nationalism: Gender and Sexuality in the Making of Nations," Ethnic and Racial Studies 21, no. 2 (1998), 245.

21. George L. Mosse, The Image of Man: The Creation of Modern Masculinity (Oxford, 1996), 4.

22. Ibid., 67-68. In addition to homosexuals, other countertypes have historically included Jews, Gypsies, vagrants, habitual criminals and the insane. 
and women, undermining the nation's internal homogeneity and deviating from its shared norms, especially those derived from religious teaching." ${ }^{3}$ In the face of a demographic decline, a feeling of national humiliation, and an uncertain political and economic future, the retraditionalization of gender and sexual norms thus provides a sense of stability and familiarity. At the same time, Putin's naturalization of Russia as the home of traditional values allows him to delegitimize attempts by his opponents to introduce liberal reforms and at the same time deflect international criticism of the country's human rights record vis-à-vis its LGBT citizens.

The politicization of homophobia in post-Soviet Russia came to a head in the 2013 "gay propaganda law," under the terms of which individuals and organizations can be fined for disseminating information about "non-traditional sexual orientations" among minors, promoting "the social equivalence of traditional and non-traditional relationships," or "the depiction of homosexual people as role models, including any mention of famous homosexuals." ${ }^{24}$ The fact that many of Russia's cultural icons-including the founder of the Ballets Russes Sergei Diaghilev, painter Léon Bakst, actress Alla Nazimova, dancers Vaslaw Nijinsky and Rudolf Nureyev, and composer Petr Tchaikovskiiwere queer was to prove problematic for Russian cultural commentators. As Philip Ross Bullock argues in the third article of this cluster, biographers of Tchaikovskii's life have either felt constrained by the homophobic social and political climate in Russia and thus shied away from examining his sexuality at all or have sought to prove that he was in fact heterosexual.

While it has been suggested that the aim of the "gay propaganda law" has been to force gays and lesbians back into the closet and make homosexuality invisible, as it was in the Soviet Union, the legislation has to some degree had a counter-productive effect. First, the top-down pressure from the state has produced bottom-up counter-pressure in the form of a wave of new or renewed LGBT activism. While for many years gays and lesbians in Russia were criticized by activists for their political apathy, the anti-gay laws have lit a fire under many sexual dissidents. In addition, the law has brought LGBT rights in Russia-a topic which the state sought to suppress - to national and international attention. The visibility the legislation has inadvertently produced should thus be seen an important component of resistance to the state-sponsored attempts to render homosexuality invisible. Moreover, Russian activists can now count on the support of Russian queer diasporas overseas. As I argue in the last of the four articles in the cluster, Russian-speaking LGBT migrants in Berlin have been active in raising awareness of the situation in their homeland and in resisting attempts to construct Russian queers as enemies of the nation. In so doing, I show how "queer diaspora" can be used as a heuristic device to think about identity, belonging, and solidarity among sexual minorities in the context of dispersal and transnational networks.

23. Richard C. M. Mole, "Nationalism and Homophobia in Central and Eastern Europe," in Koen Slootmaeckers, Heleen Touquet and Peter Vermeersch, eds., EU Enlargement and Gay Politics: The Impact of Eastern Enlargement on Rights, Activism and Prejudice (Basingstoke, 2016), 109-10.

24. The full text is available on the Rossiyskaya Gazeta Dokumenty website: http:// www.rg.ru/2013/06/30/deti-site-dok.html (Accessed on July 14, 2015). 